\title{
Dual isotopes of nitrate in Korean fertilizers and their application for identifying nitrate sources
}

\author{
${ }^{1}$ Division of Earth and Environmental Sciences, Korea Basic Science Institute, Chungbuk 28119, Republic of Korea \\ ${ }^{2}$ Department of Earth and Environmental Sciences, Pukyong National University, Busan 48513, Republic of Korea; *Corresponding author, \\ E-mail:jongsikryu@pknu.ac.kr
}

(Received: July 15, 2019; Revised accepted: November 6, 2019)

https://doi.org/10.18814/epiiugs/2019/019025

Many studies have used typical ranges of $\delta^{15} \mathrm{~N}$ and $\delta^{18} \mathrm{O}$ values to identify nitrate sources. However, it is questionable whether typical nitrate isotopes for various sources can be universally applied. Thus, for inorganic (IOF), organic $(O F)$ and plant-based compound fertilizers (PCF) in South Korea, $\delta^{15} N$ and $\delta^{18} O$ were measured to evaluate their commonly used ranges. The $\delta^{15} \mathrm{~N}$ and $\delta^{18} \mathrm{O}$ were $2.6 \pm 2.5 \%$ and $19.3 \pm 2.6 \%$ o $(n=19)$ for IOFs, $14.7 \pm 7.7 \%$ and $5.9 \pm 4.9 \%$ $(n=30)$ for $O F s$, and $10.9 \pm 6.7 \%$ and $16.0 \pm 6.1 \%$ o $(n=24)$ for PCFs, respectively. Some OFs showed relatively lower $\delta^{15} \mathrm{~N}$ than the previously reported values for $\mathrm{NO}_{3}$ fertilizers but all PCFs had both $\delta^{15} N$ and $\delta^{18} O$ similar to them, indicating that $\delta^{15} N$ and $\delta^{18} O$ for the organic material-based fertilizers were likely affected by both the composition level of the main ingredients and various additives in them. Dual isotopic data for three types of fertilizer in this study can play a crucial role in in-depth understanding the fate of natural and anthropogenic nitrate sources occurring in watershed.

\section{Introduction}

The rapid urbanization and development of riverine areas releases various contaminants into the environment, which can lead to serious environmental problems worldwide (Mayer et al., 2002; Xue et al., 2009). As one of the common contaminants in nature, nitrate $\left(\mathrm{NO}_{3}{ }^{-}-\mathrm{N}\right)$ pollution in drinking water poses a threat to human health, such as methemoglobinemia, cancer, and digestive problems, and can lead to eutrophication in surface waters (Ridder and Oehme, 1974; KrafteJacobs et al., 1997; Choi et al., 2003). Nitrate pollution is thus considered to be one of the most critical environmental issues, hence the World Health Organization (WHO) suggests a guideline value of $50 \mathrm{mg} / \mathrm{L}$ as nitrate ion $\left(\mathrm{NO}_{3}^{-}\right)$or $11 \mathrm{mg} / \mathrm{L}$ as nitrate-nitrogen $\left(\mathrm{NO}_{3}^{-}-\mathrm{N}\right)$ to protect a potential human health risk (WHO, 2008).

For these reasons, concentrations of n-containing compounds (e.g., ammonium, nitrate) and their isotopic compositions in many studies have been used to identify nitrogen sources and understand nitrogen transformation processes (e.g., mineralization, volatilization, nitrifi- cation, denitrification) during the nitrogen cycle. Especially, stable isotope techniques provide crucial information on potential sources and processes affecting isotopic compositions (e.g., Singleton et al., 2005; Diédhiou et al., 2012). For example, stable nitrogen isotope constrains sources of nitrate in agricultural areas to fertilizer and manure representing distinctive $\delta^{15} \mathrm{~N}$ values (Komor and Anderson, 1993; Iqbal et al., 1997; Curt et al., 2004).

However, only the use of nitrogen isotopes cannot differentiate other sources of nitrate, such as atmospheric deposition, synthetic fertilizers, and natural soil, due to their wide and similar ranges of $\delta^{15} \mathrm{~N}$ values (Silva et al., 2002; Fenech et al., 2012). Recent advances in analytical techniques have made it possible to analyze oxygen isotope of nitrate, which offers powerful opportunities for determining nitrate sources and understanding reactions in the environment (e.g., Casciotti et al., 2002; Mayer et al., 2002; Chmura et al., 2009). To investigate the origin of nitrate and understand various processes related to nitrogen transformation (e.g., Komor and Anderson, 1993; Vitòria et al., 2004; Li et al., 2010), many studies have compared their nitrate dual isotopic compositions to the dual isotopic ranges for the main potential nitrate sources which was previously compiled (Kendall, 1998). It is questionable whether the dual isotopic ranges suggested in the previous studies could be representative of nitrate sources in all countries. For example, the degree of fermentation of raw materials in organic fertilizer and the type of main ingredients and additives used in inorganic fertilizer could impact on isotope ratios. Therefore, it is necessary to revisit compiled previous data to confirm the above approach, especially in South Korea.

To this end, we collected three different types of Korean fertilizers and investigated dual isotopic compositions of nitrate. Then, on plot of $\delta^{15} \mathrm{~N}$ and $\delta^{18} \mathrm{O}$ values, our results were presented with typical ranges for main sources of nitrate to evaluate difference between them. In addition, in terms of identification of sources, nitrate isotopes from previous Korean case studies were reevaluated with the results in this study.

\section{Materials and Methods}

\section{Samples}

A total of 73 fertilizers commonly used in South Korea were purchased from many retailers in personal throughout South Korea during 


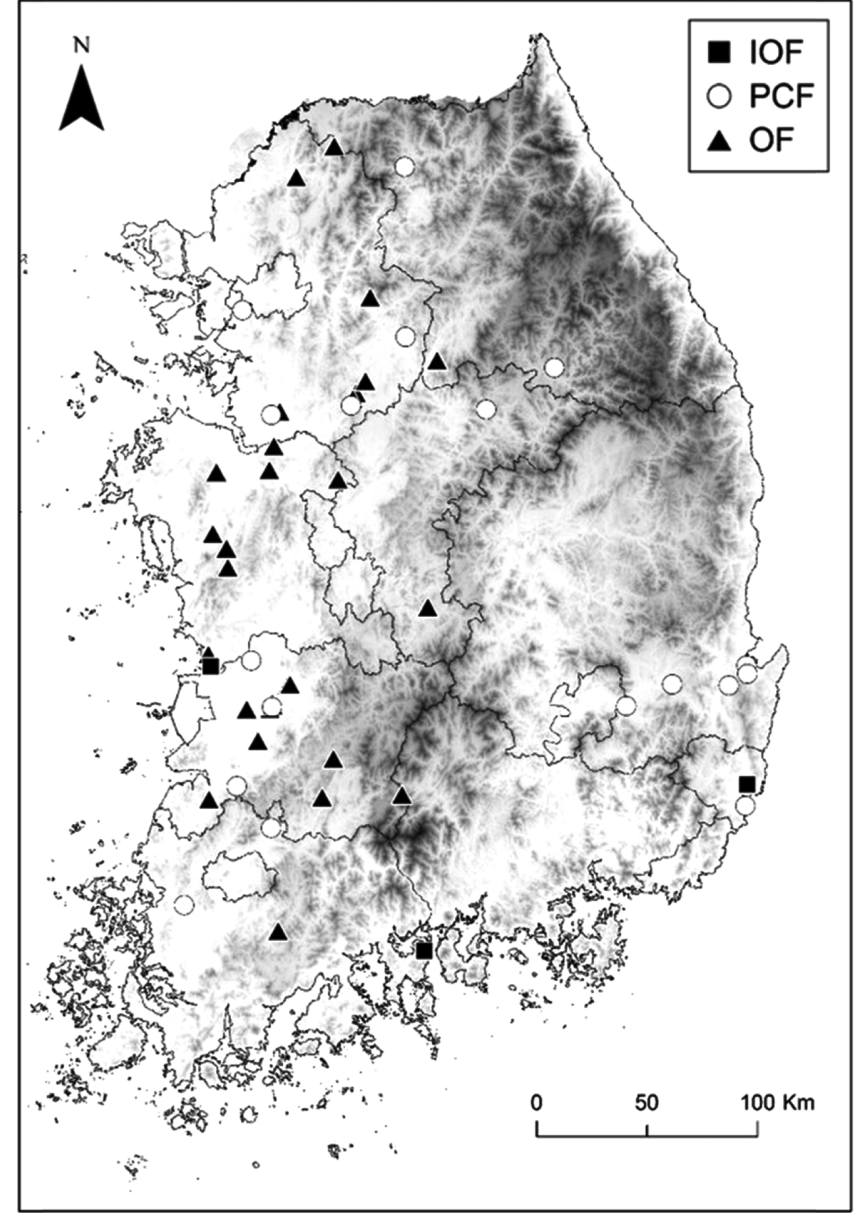

Figure 1. Map showing production sites of inorganic fertilizer (IOF, closed square), plant-based compound fertilizer (PCF, open circle), and organic fertilizer (OF, closed triangle) manufactured in South Korea. The darker areas represent lands located in the higher altitudes.

the period of 2011-2012 (Fig. 1). The fertilizers were packed in various sizes from $1 \mathrm{~kg}$ to $20 \mathrm{~kg}$. Based on the information attached in each container of the fertilizer, the Korean fertilizer samples used in this study were classified into three types, inorganic (synthetic; $n=19$ ), organic $(n=30)$, and plant-based compound fertilizers $(n=24)$; hereafter, each fertilizer was abbreviated by IOF, OF, and PCF, respectively. The IOF samples were manufactured by three major companies (Pungnong, Namhae Chemical, Dongbu Hannong) in South Korea, and the others were produced from small business companies located in each Province. Thus, the samples are regarded as representative Korean fertilizers, with excluding extensive mountainous areas (Fig. 1). The IOF with N, P, and K compounds includes N content from 11 to $30 \%$ (average $19.8 \pm 6.51 \%$ ). The OF mostly consists of chicken, pig, and cattle manure mixed with sawdust and bark, and includes a variety of additives such as slaughter byproducts, and enzyme. The PCF with a small $\mathrm{N}$ compound ( $4.0 \sim 6.0 \%$, average $4.5 \pm 0.8 \%$ ) includes soybean, castor, rapeseed, and rice bran meals as main ingredients, and various additives such as fish meal, powdered bone, zeolite and dolomitic limestone.

\section{Sample Preparation}

Samples were crushed in a shatter box equipped with a tungsten carbide grinding container (Retsch MM400, Germany). About $2.0 \mathrm{~g}$ of the powdered fertilizers were soaked in $40 \mathrm{~mL}$ MQ water at room temperature for $24 \mathrm{~h}$. The mixture was centrifuged at $4,000 \mathrm{rpm}$ for 30 minutes (Combi 408, Hanil Science Co. Ltd., Korea), and the supernatant was passed through a $0.45-\mu \mathrm{m}$ pore size polypropylene syringe filter (25 mm GD/X PVDF, Whatman, UK), adjusted to $\mathrm{pH} 10-11$ using $1 \mathrm{~N} \mathrm{NaOH}$ (Guaranteed reagent, Junsei) to inhibit microbial activity, and stored in a refrigerator at $4^{\circ} \mathrm{C}$ pending analysis.

Nitrate in the samples was converted to nitrous oxide $\left(\mathrm{N}_{2} \mathrm{O}\right)$ using the denitrifier technique described in Sigman et al. (2001). In short, Pseudomonas aureofaciens (ATCC ${ }^{\circledR} 13985^{\mathrm{TM}}$ ) was cultivated at $27^{\circ} \mathrm{C}$ in media consisting of $30 \mathrm{~g} / \mathrm{L}$ tryptic soy broth (TSB, BD; Ref \#211825, USA), $0.5 \mathrm{~g} / \mathrm{L}\left(\mathrm{NH}_{4}\right)_{2} \mathrm{SO}_{4}$ (ACS grade, Fisher Scientific), $4.9 \mathrm{~g} / \mathrm{L} \mathrm{KH}_{2}$ $\mathrm{PO}_{4}$ (Laboratory grade, Fisher Scientific), and $1 \mathrm{~g} / \mathrm{L} \mathrm{KNO}$ (ACS grade, Acros Organics). After 6-10 days, working cultures were centrifuged, concentrated eightfold, and divided into 2-mL aliquots. Then, $0.1 \mathrm{~mL}$ of antifoaming emulsion (Antifoam B, Sigma Aldrich, USA) was added to prevent foam during the helium-purging process. After the purging, water sample reacting with fertilizers was added to the sample vials, and the amount of injected samples was determined based on $\mathrm{NO}_{3}{ }^{-}$ concentration. The sample vials were placed up-side down at room temperature overnight to prevent leakage during the conversion of $\mathrm{NO}_{3}{ }^{-}$to $\mathrm{N}_{2} \mathrm{O}$, and approximately $0.1 \mathrm{~mL}$ of $10 \mathrm{~N} \mathrm{NaOH}$ was added before analyzing isotopes to inhibit bacterial activity and scavenge the dissolved $\mathrm{CO}_{2}$ (Casciotti et al., 2002).

\section{Isotope Analysis}

From gases formed by the denitrifier technique mentioned above, $\mathrm{N}_{2} \mathrm{O}$ was stripped through chemical traps and GC column installed in a TraceGas Pre-Concentrator (IsoPrime, UK), and its isotopic composition was analyzed by online linked IsoPrime isotope ratio mass spectrometer (GV Instruments, UK) at the Korea Basic Science Institute (KBSI). All ${ }^{15} \mathrm{~N} /{ }^{14} \mathrm{~N}$ and ${ }^{18} \mathrm{O} /{ }^{16} \mathrm{O}$ ratios are reported in delta $(\delta)$ notation relative to Air and Vienna Standard Mean Ocean Water (VSMOW), respectively:

$$
\begin{aligned}
& \delta^{15} \mathrm{~N}=\left[\left({ }^{15} \mathrm{~N} /{ }^{14} \mathrm{~N}\right)_{\text {sample }}\left(\left({ }^{15} \mathrm{~N} /{ }^{14} \mathrm{~N}\right)_{\text {Air }}-1\right] \times 1000\right. \\
& \delta^{18} \mathrm{O}=\left[\left({ }^{18} \mathrm{O} /{ }^{16} \mathrm{O}\right)_{\text {sample }} /\left({ }^{18} \mathrm{O} /{ }^{16} \mathrm{O}\right)_{\text {vSmOw }}-1\right] \times 1000
\end{aligned}
$$

The correction factor method was used to correct mass fractionation and instrumental mass bias during the measurement because it is suitable for raw $\delta^{15} \mathrm{~N}$ and $\delta^{18} \mathrm{O}$ correction (Rock and Ellert, 2007; Xue et al., 2010). The correction factor (CF) is calculated as the ratio of the difference between the certified and the measured isotope (i.e., $\delta^{15} \mathrm{~N}$ or $\delta^{18} \mathrm{O}$ ) values of two reference materials:

$$
\begin{aligned}
& \mathrm{CF}_{15 \mathrm{~N}}=\left(\delta^{15} \mathrm{~N}_{\mathrm{R} 1}-\delta^{15} \mathrm{~N}_{\mathrm{R} 2}\right)_{\text {certified }} /\left(\delta^{15} \mathrm{~N}_{\mathrm{R} 1}-\delta^{15} \mathrm{~N}_{\mathrm{R} 2}\right)_{\text {measured }} \\
& \mathrm{CF}_{18 \mathrm{O}}=\left(\delta^{18} \mathrm{O}_{\mathrm{R} 1}-\delta^{18} \mathrm{O}_{\mathrm{R} 2}\right)_{\text {certified }} /\left(\delta^{18} \mathrm{O}_{\mathrm{R} 1}-\delta^{18} \mathrm{O}_{\mathrm{R} 2}\right)_{\text {measured }}
\end{aligned}
$$

, where reference materials R1 and R2 are IAEA-NO3 and USGS-34, respectively. The measured $\delta^{15} \mathrm{~N}$ and $\delta^{18} \mathrm{O}$ values of the samples were corrected using the following equations:

$$
\delta^{15} \mathrm{~N}_{\text {sample }}=\delta^{15} \mathrm{~N}_{\mathrm{R} 1 \text {, certified }}+\left(\delta^{15} \mathrm{~N}_{\text {sample, measured }}-\delta^{15} \mathrm{~N}_{\mathrm{R} 1 \text {, measured }}\right) \times \mathrm{CF}_{15 \mathrm{~N}}
$$




$$
\delta^{18} \mathrm{O}_{\text {sample }}=\delta^{18} \mathrm{O}_{\mathrm{R} 1, \text { certified }}+\left(\delta^{18} \mathrm{O}_{\text {sample, measured }}-\delta^{18} \mathrm{O}_{\mathrm{R} 1, \text { measured }}\right) \times \mathrm{CF}_{18 \mathrm{O}} \text { (6) }
$$

Replicate samples were analyzed (at least two samples), and uncertainties are reported as two standard deviations $(2 \sigma)$. The two reference materials, IAEA-NO3 and USGS-34 (4.7 $\pm 0.2 \%$ and $-1.8 \pm 0.2 \%$ for $\delta^{15} \mathrm{~N}$, and $25.6 \pm 0.4 \%$ and $-27.9 \pm 0.6 \%$ for $\delta^{18} \mathrm{O}$, respectively), were repeatedly measured during the period of analysis. IAEA-NO3 yielded $4.7 \pm 0.2 \%$ for $\delta^{15} \mathrm{~N}$ and $25.6 \pm 0.6 \%$ for $\delta^{18} \mathrm{O}(2 \sigma, \mathrm{n}=40)$, and USGS-34 yielded $-1.8 \pm 0.2 \%$ for $\delta^{15} \mathrm{~N}$ and $-27.9 \pm 0.7 \%$ for $\delta^{18} \mathrm{O}(2 \sigma, \mathrm{n}=40)$, all of which in a good agreement with the certified values.

\section{Results and Discussion}

\section{Nitrate Isotopes for Korean Organic and Inorganic Fer- tilizers}

Dual isotopic compositions of nitrate stripped from all inorganic, organic and plant-based compound fertilizer samples (IOF, OF and
PCF) were given in Table 1. The nitrogen isotope composition of the IOF $\left(\delta^{15} \mathrm{~N}_{\mathrm{IOF}}\right)$ exhibited a relatively narrow range compared to those of the other fertilizers. The $\delta^{15} \mathrm{~N}_{\mathrm{IOF}}$ values ranged from -1.1 to $7.6 \%$ (average $2.6 \pm 2.5 \%, \mathrm{n}=19$ ). In contrast, $\delta^{15} \mathrm{~N}$ values of the $\mathrm{OF}$ and PCF $\left(\delta^{15} \mathrm{~N}_{\mathrm{OF}}\right.$ and $\delta^{15} \mathrm{~N}_{\mathrm{PCF}}$, respectively) had the relatively wide ranges from -1.2 to $26.2 \%$ (average $14.7 \pm 7.7 \%$ o, $\mathrm{n}=30$ ), and from -1.0 to $25.5 \%$ o (average $10.9 \pm 6.7 \%$, $\mathrm{n}=24$ ), respectively.

Most of the $\delta^{15} \mathrm{~N}_{\mathrm{IOF}}$ and $\delta^{15} \mathrm{~N}_{\mathrm{OF}}$ values in this study were within the ranges representative of chemical fertilizer and manure (Hübner, 1986; Aravena et al., 1993; Kendall, 1998, Vitòria et al., 2004; Fiorentino et al., 2015) (Fig. 2). The range of $\delta^{15} \mathrm{~N}_{\mathrm{OF}}$ values was widest among all types of fertilizer, and much wider than the reported range of between ca. 10 and $>20 \%$ for animal waste (Tihansky and Sacks, 1997 and references therein). This result would be triggered by various kinds of main ingredients and additives. By comparison, the PCFs have a wider range of $\delta^{15} \mathrm{~N}$ values than the IOFs due to their diverse additives (including a small amount of $\mathrm{N}$ derived from inorganic compound, average $4.5 \pm 0.8 \%$ ). Of organic material-based fertilizers (OF and PCF), the

Table 1. Dual isotope compositions of nitrate derived from three types of Korean fertilizers (unit in \%o)

\begin{tabular}{|c|c|c|c|c|c|c|c|c|c|c|c|c|c|c|}
\hline \multicolumn{5}{|c|}{ Inorganic fertilizer (IOF; $\mathrm{n}=19)$} & \multicolumn{5}{|c|}{ "Organic fertilizer $(\mathrm{OF} ; \mathrm{n}=30)$} & \multicolumn{5}{|c|}{ Plant-based compound fertilizer (PCF; $n=24)$} \\
\hline Sample & $\delta^{15} \mathrm{~N}$ & $2 \sigma^{(a)}$ & $\delta^{18} \mathrm{O}$ & $2 \sigma$ & Sample & $\delta^{15} \mathrm{~N}$ & $2 \sigma$ & $\delta^{18} \mathrm{O}$ & $2 \sigma$ & Sample & $\delta^{15} \mathrm{~N}$ & $2 \sigma$ & $\delta^{18} \mathrm{O}$ & $2 \sigma$ \\
\hline IOF-1 & 3.8 & 0.1 & 18.9 & 0.7 & OF-1 & 20.4 & 0.3 & 7.4 & 0.1 & PCF-1 & 8.0 & 1.1 & 19.4 & 1.2 \\
\hline IOF-2 & 5.3 & 0.2 & 16.5 & 0.8 & $\mathrm{OF}-2$ & -0.6 & 0.1 & 8.0 & 1.0 & PCF-2 & 10.2 & 0.1 & 11.7 & 0.6 \\
\hline IOF-3 & 6.2 & 0.3 & 17.6 & 0.5 & $\mathrm{OF}-3$ & 21.7 & 1.0 & 7.4 & 0.4 & PCF-3 & 2.0 & 0.3 & 19.4 & 0.6 \\
\hline IOF-4 & 3.9 & 0.0 & 17.3 & 0.7 & $\mathrm{OF}-4$ & 18.8 & 0.4 & 8.8 & 0.1 & PCF-4 & 14.6 & 0.7 & 9.4 & 0.1 \\
\hline IOF-5 & 5.6 & 0.0 & 21.7 & 0.3 & OF-5 & 15.0 & 0.2 & 11.0 & 0.5 & PCF-5 & 17.8 & 0.3 & 17.7 & 0.1 \\
\hline IOF-6 & 4.7 & 0.1 & 19.0 & 0.7 & OF-6 & 15.7 & 0.5 & 7.1 & 0.6 & PCF-6 & 15.4 & 0.7 & 11.0 & 1.2 \\
\hline IOF-7 & 0.5 & 0.8 & 22.7 & 0.4 & $\mathrm{OF}-7$ & 10.9 & 0.1 & 1.6 & 0.8 & PCF-7 & 13.2 & 0.2 & 18.3 & 0.5 \\
\hline IOF-8 & 0.9 & 0.6 & 21.8 & 1.1 & OF-8 & 17.2 & 0.3 & 1.0 & 0.1 & PCF-8 & 7.6 & 0.0 & 19.6 & 0.0 \\
\hline IOF-9 & 1.7 & 0.6 & 22.6 & 1.5 & OF-9 & 23.2 & 0.1 & 14.4 & 0.4 & PCF-9 & 0.7 & 0.1 & 10.6 & 0.8 \\
\hline IOF-10 & 0.4 & 0.1 & 21.9 & 1.2 & OF-10 & 21.7 & 0.2 & 3.5 & 0.2 & PCF-10 & 15.3 & 0.1 & 12.3 & 0.7 \\
\hline IOF-11 & 1.0 & 0.1 & 19.0 & 0.3 & OF-11 & 2.1 & 0.2 & 4.4 & 0.2 & PCF-11 & 8.7 & 0.2 & 12.7 & 0.6 \\
\hline IOF-12 & 3.0 & 0.0 & 20.9 & 0.6 & OF-12 & 7.5 & 0.3 & -4.0 & 0.8 & PCF-12 & 12.5 & 0.2 & 13.8 & 0.1 \\
\hline IOF-13 & 2.0 & 0.1 & 20.4 & 0.2 & OF-13 & 24.4 & 0.2 & 10.5 & 1.3 & PCF-13 & 21.6 & 0.5 & 12.4 & 1.2 \\
\hline IOF-14 & -0.9 & 0.6 & 15.1 & 0.2 & OF-14 & 11.5 & 0.3 & 14.1 & 0.2 & PCF-14 & 12.0 & 0.5 & 31.0 & 0.2 \\
\hline IOF-15 & 1.0 & 0.0 & 22.5 & 1.4 & OF-15 & 24.0 & 0.8 & 7.6 & 0.1 & PCF-15 & 15.4 & 0.1 & 1.8 & 0.8 \\
\hline IOF-16 & 3.8 & 0.4 & 16.5 & 0.0 & OF-16 & -1.2 & 0.1 & 4.4 & 0.6 & PCF-16 & 6.8 & 0.1 & 24.8 & 1.1 \\
\hline IOF-17 & -0.4 & 0.3 & 18.9 & 0.6 & OF-17 & 12.2 & 0.0 & 5.4 & 0.1 & PCF-17 & 1.8 & 0.3 & 21.1 & 0.2 \\
\hline IOF-18 & -1.1 & 0.3 & 14.1 & 0.3 & OF-18 & 22.6 & 0.2 & 12.5 & 0.2 & PCF-18 & 15.5 & 0.2 & 17.3 & 0.1 \\
\hline \multirow[t]{12}{*}{ IOF-19 } & 7.6 & 0.2 & 19.7 & 1.4 & OF-19 & 17.7 & 0.5 & 5.8 & 0.0 & PCF-19 & 15.8 & 0.1 & 15.0 & 0.4 \\
\hline & & & & & $\mathrm{OF}-20$ & -1.0 & 0.1 & -2.8 & 0.1 & PCF-20 & 4.7 & 0.6 & 22.6 & 0.7 \\
\hline & & & & & OF-21 & 13.0 & 0.0 & 9.3 & 0.2 & PCF-21 & 6.0 & 0.1 & 18.6 & 0.2 \\
\hline & & & & & OF-22 & 9.4 & 0.2 & -4.5 & 0.8 & PCF-22 & -1.0 & 0.0 & 20.3 & 0.2 \\
\hline & & & & & $\mathrm{OF}-23$ & 13.2 & 0.1 & 10.0 & 0.4 & PCF-23 & 12.2 & 0.3 & 10.2 & 0.9 \\
\hline & & & & & OF-24 & 26.2 & 0.2 & 10.7 & 0.3 & PCF-24 & 25.5 & 0.9 & 12.9 & 1.3 \\
\hline & & & & & $\mathrm{OF}-25$ & 17.1 & 1.0 & 2.6 & 0.6 & & & & & \\
\hline & & & & & $\mathrm{OF}-26$ & 13.2 & 0.0 & 3.0 & 0.4 & & & & & \\
\hline & & & & & OF-27 & 15.4 & 0.2 & 1.0 & 0.2 & & & & & \\
\hline & & & & & $\mathrm{OF}-28$ & 22.9 & 0.2 & 6.0 & 0.3 & & & & & \\
\hline & & & & & OF-29 & 14.8 & 0.1 & 7.0 & 0.1 & & & & & \\
\hline & & & & & OF-30 & 12.1 & 0.0 & 4.5 & 0.0 & & & & & \\
\hline
\end{tabular}

(a) Uncertainty: two standard deviations 

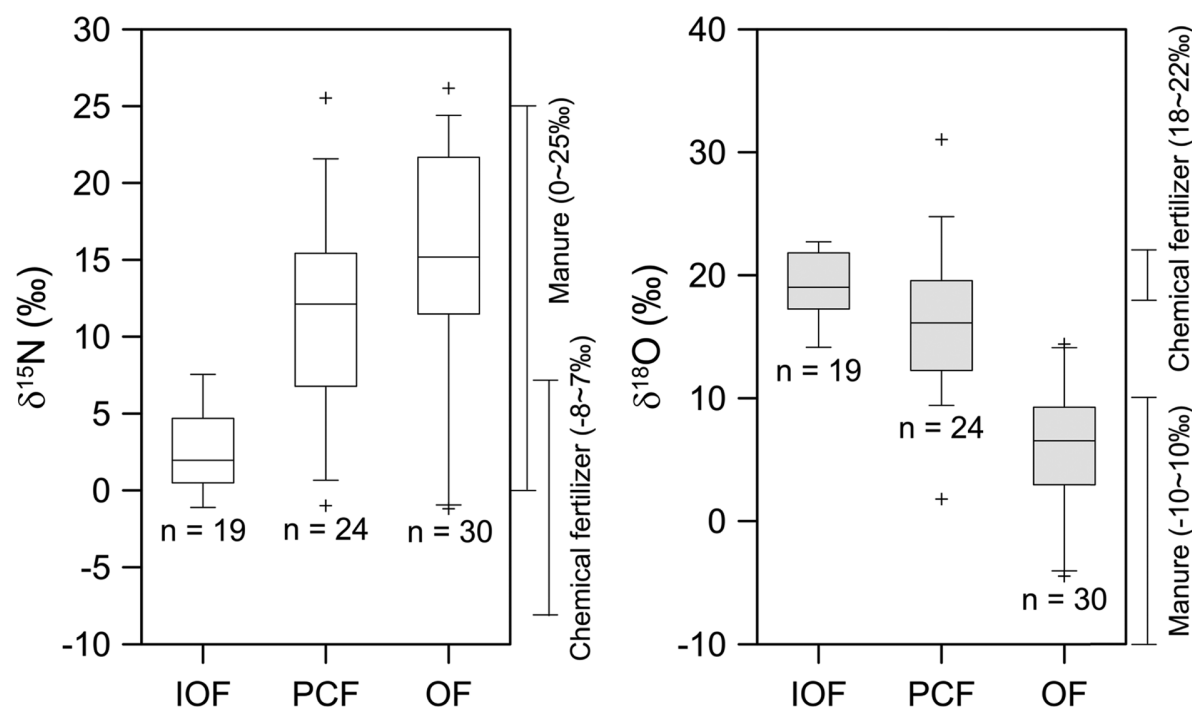

Figure 2. Box-Whisker diagrams showing the $\delta^{15} N(a)$ and $\delta^{18} O$ (b) ranges of nitrate for inorganic fertilizer (IOF), plant-based compound fertilizer (PCF) and organic fertilizer $(\mathrm{OF})$ collected from South Korea. 50\% of data (interquartile, IQR) is expressed in a box, and lower and upper whiskers are defined by $5^{\text {th }}$ percentile $-1.5 \times I Q R$ and $95^{\text {th }}$ percentile $+1.5 \times I Q R$, respectively.

$\delta^{18} \mathrm{O}$ values of meteoric water in South Korea mostly varies between -11 and $-5 \%$ (Kim and Nakai, 1988; Lee and Chung, 1997; Moon et al., 2007). The $\delta^{18} \mathrm{O}_{\mathrm{PCF}}$ values lie between those of the IOFs and OFs and it would be explained by both additives and nitrification processes.

\section{Factors Determining Dual Isotopic Ranges of Korean Fertilizers}

On the plot of $\delta^{15} \mathrm{~N}$ and $\delta^{18} \mathrm{O}$ values, IOFs and OFs were entirely on the representative areas of $\mathrm{NO}_{3}$ fertilizer and manure, respectively (Fig. 3). Interestingly, PCFs overall plotted on the $\mathrm{NO}_{3}$ fertilizer cluster and on the upper part of manure cluster, and they were also between both of the clusters (Fig. 3). Isotopic compositions of PCFs are likely to move toward manure cluster, not toward clusters of soil- $\mathrm{N}$ and $\mathrm{NH}_{4}$ in fertilizer. It is likely to result from mixing between manure (or OFs) and chemical fertilizer. Nonetheless, it is

samples from $25^{\text {th }}$ to $75^{\text {th }}$ percentiles generated ${ }^{15} \mathrm{~N}$-enriched nitrate (approximately 6.8 22\%o), regardless of their main ingredients (Fig. 2). According to previous study reporting $\delta^{15} \mathrm{~N}$ values of Korean organic fertilizers (Shin et al., 2017), approximately $79 \%$ of both plant-based and animal-based organic fertilizers (PBOF, $n=6$ and ABOF, $n=22$, respectively) produced nitrate with $\delta^{15} \mathrm{~N}$ values $>11 \%$.

Meanwhile, it is important to note that PBOF contained more ${ }^{15} \mathrm{~N}$ depleted organic $\mathrm{N}$ and total $\mathrm{N}$ than those of ABOF. According to the South Korea Rural Development Administration (Rural Development Administration, 2012), non-fermented raw materials are used to produce $\mathrm{PBOF}$, and microbial biodegradation would not occur in the manufacturing process. In addition, composting process, degradation of organic waste by microbial communities, was typically performed for OF, but not for PCF, causing release of ${ }^{15} \mathrm{~N}$-depleted $\mathrm{NH}_{3}$ gas $(\mathrm{Ni}$ et al., 2010; Shin et al., 2017). These imply that nitrate released from PBOF (or PCF) is characterized by the lower $\delta^{15} \mathrm{~N}$ values through nitrification processes compared to ABOF (or OF) if they are in the same decomposition level in subsurface environment.

The oxygen isotope compositions of IOFs and OFs $\left(\delta^{18} \mathrm{O}_{\mathrm{IOF}}\right.$ and $\delta^{18} \mathrm{O}_{\mathrm{OF}}$, respectively) differed from those of PCFs (Table 1, Fig. 2). The $\delta^{18} \mathrm{O}_{\mathrm{IOF}}$ and $\delta^{18} \mathrm{O}_{\mathrm{OF}}$ values ranged from 14.1 to $22.7 \%$ o (average $19.3 \pm 2.6 \%$ o, $\mathrm{n}=19$ ) and from -4.5 to $14.4 \%$ o (average $5.9 \pm 4.9 \%$, $\mathrm{n}$ $=30$ ), respectively. In contrast, the PCFs exhibited $\delta^{18} \mathrm{O}$ values ranging from 1.8 to $31.0 \%$ (average $16.0 \pm 6.1 \%$, $n=24$ ). With an exception on two samples, the $\delta^{18} \mathrm{O}_{\mathrm{IOF}}$ values were similar to but slightly wider than the indicative range $\left(18 \sim 22 \%\right.$ ) of $\mathrm{NO}_{3}$ fertilizer (Amberger and Schmidt, 1987) because all three oxygen atoms in the inorganic fertilizers are from atmospheric $\mathrm{O}_{2}$ with $\delta^{18} \mathrm{O}$ value of $23 \%$, globally homogeneous (Kroopnick and Craig, 1972; Koch, 2007). The OFs had comparatively low $\delta^{18} \mathrm{O}$ values, likely less than $15 \%$ (Wassenaar, 1995). The result indicates that $\delta^{18} \mathrm{O}$ values of nitrate are determined by microbial nitrification. Typically, one-third of the oxygen atoms in nitrate are derived from air, and the rest from ambient water that nitrate is formed (Andersson and Hooper, 1983; Kumar et al., 1983; DiSpirito and Hooper, 1986). more reasonable that the behavior of isotopes of PCFs was due to nitrification occurring following manufacturing processes. As suggested in previous study (Shin et al., 2017), $\mathrm{NH}_{3}$ gas volatilization would occur during the laboratory extraction, subsequently resulting in ${ }^{15} \mathrm{~N}$-enriched nitrate. The degree of fermentation of main organic materials would mainly affect isotopes of PCFs. For OFs, increase in dual isotope compositions would not be observed during the eluting nitrate in this study because main ingredients of OFs had been fermented during manufacturing processes (e.g., composting process); it is likely to be no clear isotopic fractionation during the leaching process.

The $\delta^{15} \mathrm{~N}$ and $\delta^{18} \mathrm{O}$ values of IOF, PCF and OF were approximately revisited (Fig. 4), considering the representative clusters such as inorganic fertilizer and manure, and the range indicative of microbial

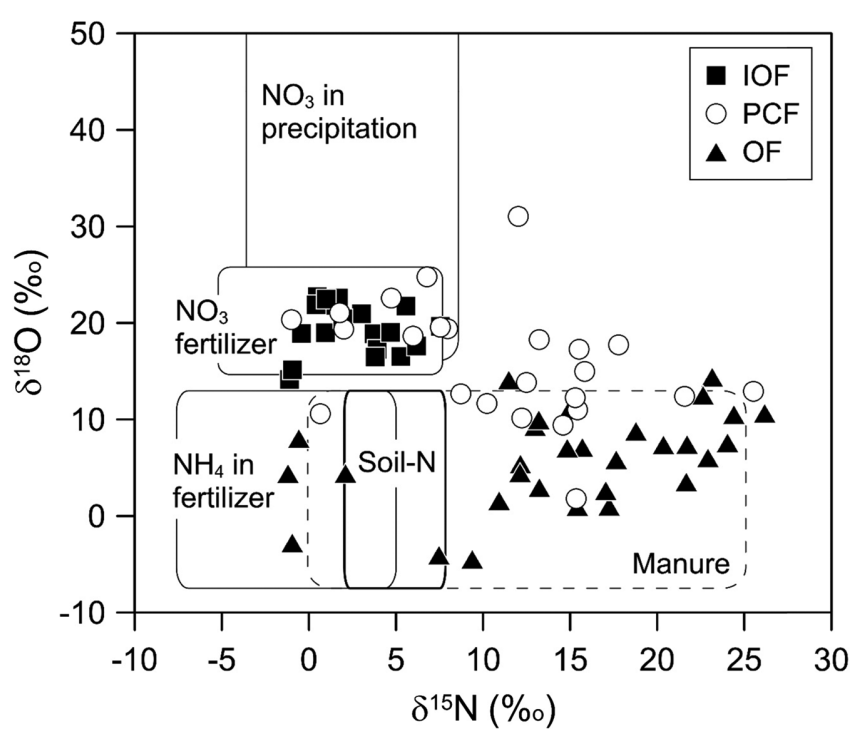

Figure 3. Plot of $\delta^{15} \mathrm{~N}$ and $\delta^{18} \mathrm{O}$ values of nitrate for various Korean fertilizers superimposed on typical ranges of nitrate from various sources (Kendall, 1998). 


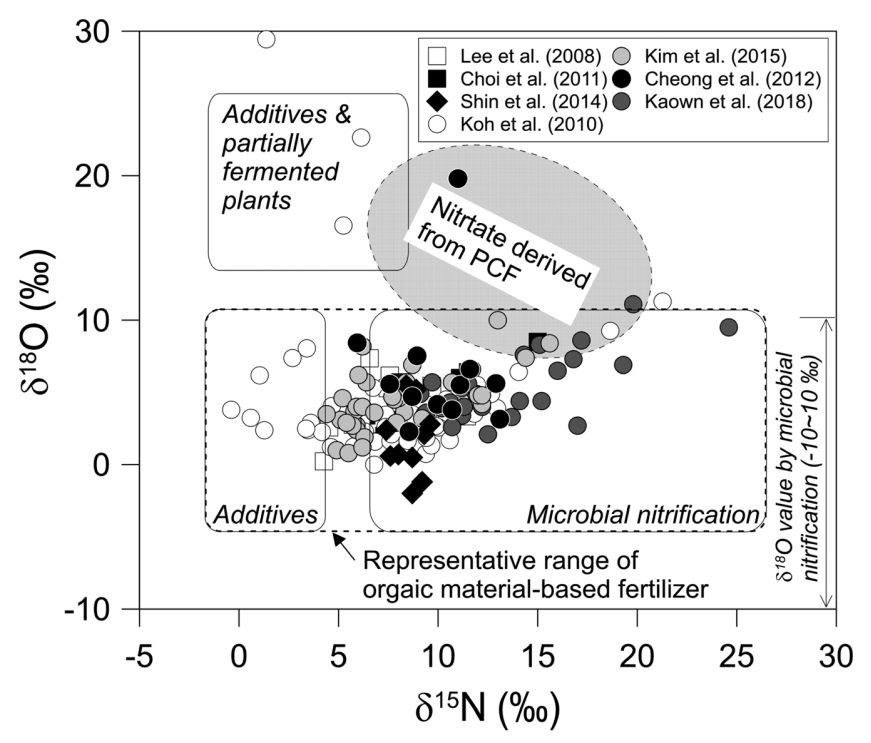

Figure 4. Plot of $\delta^{15} \mathrm{~N}$ and $\delta^{18} \mathrm{O}$ values of nitrate from previous studies (Lee et al., 2008; Koh et al., 2010; Choi et al., 2011; Cheong et al., 2012; Shin et al., 2014; Kim et al., 2015; Kaown et al., 2018) in South Korea superimposed on the revised fields of nitrate from fertilizers determined in this study. Main factors determining the isotopic ranges were shown in italic.

nitrification, i.e., $-10 \%$ to $10 \%$ for $\delta^{18} \mathrm{O}$ values (Mayer et al., 2001; Michalski et al., 2004; Kendall et al., 2007). $\delta^{15} \mathrm{~N}$ values of organic material-based fertilizers are closely related to the degree of fermentation of organic fertilizers. According to manure-hydrolysis experiment conducted by Lee et al. (2011), $\delta^{15} \mathrm{~N}$ of manure rapidly increased due to $\mathrm{NH}_{3}$ volatilization during the hydrolysis. As mentioned earlier, OFs experienced composting process during manufacturing processes, implying that organic wastes were sufficiently degraded. Thus, for OFs, nitrogen isotope fractionation was negligible in this study even though $\mathrm{NH}_{3}$ would be released by volatilization process. Most OFs plotted in the cluster characterized by microbial nitrification processes. PCFs were produced by many small business manufacturers and the main ingredients used in PCFs would be at different decomposition level. In addition, the PCFs included the different kind of additives. For the reasons, dual isotopic ranges of PCFs can be away from manure cluster, with $\delta^{18} \mathrm{O}$ value higher than those in previous studies (approximately $10 \%$ ). Nonetheless, we should consider possibility that dual isotopic compositions originating from PCFs is subsequently in the manure cluster due to microbial nitrification processes occurring in subsurface environment.

\section{Application for Identifying Nitrate Sources}

Many studies conducted in various countries have used a typical cluster of $\delta^{15} \mathrm{~N}$ and $\delta^{18} \mathrm{O}$ values (Kendall, 1998) to determine nitrate sources and understand the reactions in the study area. In many previous studies in South Korea, both of the isotopes have been determined to trace nitrate sources in groundwater and surface water (Lee et al., 2008; Koh et al., 2010; Choi et al., 2011; Cheong et al., 2012; Shin et al., 2014; Kaown et al., 2018). To evaluate our results, the isotope data from previous Korean studies were plotted on the revised fields of $\delta^{15} \mathrm{~N}$ and $\delta^{18} \mathrm{O}$ determined in this study (Fig. 4).

Dissolved nitrate in the Han River (HR) was explained by soil organic matter in the North Han River and by either manure/sewage in the South Han River (Lee et al., 2008). However, according to our results, the dissolved nitrate could be mainly derived from OFs with markedly low $\delta^{15} \mathrm{~N}$ value and fermented PCFs, and OFs; the both organic material-based fertilizers would be evolved into nitrate with the higher isotopic compositions because of transformation processes (e.g., volatilization, nitrification, denitrification) occurring in agricultural field. Considering the transformation processes, the nitrate with relatively low isotopic values was closely related to soil organic matter as well. This possibility seems to be reasonable because the sampling sites in the HR Basin are dominated by agricultural land use. In similar, the water samples collected from areas with dominant agricultural land uses within the Geum River (GR) Basin and Odae stream (OS) watershed were characterized by nitrate derived from a mixture of manure-derived fertilizers (Choi et al., 2011; Shin et al., 2014). The suggestion in the previous studies is also supported by our results, with a consideration for transformation processes as mentioned above.

In addition, our results revealed that the nitrate sources in groundwater collected from eastern part of the study area were mainly derived from organic fertilizer including manure, while those in groundwater collected from the other parts was attenuated by denitrification processes (Kaown et al., 2018). A study conducted in mid-western South Korea investigated the sources of nitrate in the shallow groundwater of an agricultural area, and indicated that it is derived predominantly from several sources; i.e., septic waste, inorganic fertilizers, and atmospheric deposition (Koh et al., 2010). Nitrate of groundwater in areas where paddy fields are exclusively distributed was mainly derived from two main sources (i.e., soil organic matter and manure-based fertilizers; Kim et al., 2015).

Although Cheong et al. (2012) indicated that most samples were in the representative range of manure and sewage (Figs. 2 and 3), our results revealed that nitrate in their studies could be mainly derived from soil organic N, organic material-based fertilizers (i.e., PCFs and OFs). These results suggest that determination of the typical ranges of $\delta^{15} \mathrm{~N}$ and $\delta^{18} \mathrm{O}$ for the dominant nitrate sources in the study area should be completed before attempting to identify nitrate sources and understand related processes using the $\delta^{15} \mathrm{~N}$ and $\delta^{18} \mathrm{O}$ values of nitrate.

\section{Conclusions}

The dual isotopic compositions of nitrate $\left(\delta^{15} \mathrm{~N}\right.$ and $\left.\delta^{18} \mathrm{O}\right)$ for three types of Korean fertilizer were determined and their usefulness for identifying nitrate sources was evaluated, with a suggestion for dual isotopic ranges of nitrate derived from fertilizer. The average $\delta^{15} \mathrm{~N}$ and $\delta^{18} \mathrm{O}$ values were $2.6 \pm 2.5 \%$ and $19.3 \pm 2.6 \%$ for inorganic fertilizer (IOF, $\mathrm{n}=19$ ), $14.7 \pm 7.7 \%$ and $5.9 \pm 4.9 \%$ organic fertilizers (OF, $n$ $=30$ ), and $10.9 \pm 6.7 \%$ and $16.0 \pm 6.1 \%$ for plant-based compound fertilizer (PCF, $\mathrm{n}=24$ ), respectively. The combined $\delta^{15} \mathrm{~N}$ and $\delta^{18} \mathrm{O}$ values enabled identification of the inorganic fertilizers and organic materialbased fertilizers. On the plot of $\delta^{15} \mathrm{~N}$ and $\delta^{18} \mathrm{O}$ values, PCFs varied between $\mathrm{NO}_{3}$ fertilizer and manure clusters. A type of additives and amount of $\mathrm{N}$ compound in the PCFs would not be related to the behavior of isotopic values for PCFs. The $\delta^{15} \mathrm{~N}$ and $\delta^{18} \mathrm{O}$ values of PCFs would 
be dependent on their decomposition levels of main ingredients used during manufacturing processes. In similar, manure-based organic fertilizers can lie on the representative soil cluster as depending on various additives. The results indicate that the typical ranges of $\delta^{15} \mathrm{~N}$ and $\delta^{18} \mathrm{O}$ for the dominant nitrate sources should be carefully determined to identify the origin and understand the fate of nitrate in South Korea.

\section{Acknowledgements}

This work was supported by the National Research Council of Science \& Technology (NST) grant by the Korea government (MSIP) (No. CAP-17-05-KIGAM).

\section{References}

Amberger, A., and Schmidt, H.L., 1987, The natural isotope content of nitrate as an indicator of its origin. Geochimica et Cosmochimica Acta, v. 51, pp. 2699-2705.

Andersson, K.K., and Hooper, A.B., 1983, $\mathrm{O}_{2}$ and $\mathrm{H}_{2} \mathrm{O}$ are each the source of one $\mathrm{O}$ in $\mathrm{NO}_{2}{ }^{-}$produced from $\mathrm{NH}_{3}$ by Nitrosomonus: ${ }^{15} \mathrm{~N}-\mathrm{NMR}$ evidence. FEBS Letters, v. 164, pp. 236-240.

Aravena, R., Evans, M.L., and Cherry, J.A., 1993, Stable isotopes of oxygen and nitrogen in source identification of nitrate from septic systems. Groundwater, v. 31, pp. 180-186.

Casciotti, K.L., Sigman, D.M., Hastings, M.G., Böhlke, J.K., and Hilkert, A., 2002, Measurement of the oxygen isotopic composition of nitrate in seawater and freshwater using the denitrifier method. Analytical Chemistry, v. 74, pp. 4905-4912.

Cheong, J.Y., Hamm, S.Y., Lee, J.H., Lee, K.S., and Woo, N.C., 2012, Groundwater nitrate contamination and risk assessment in an agricultural area, South Korea. Environmental Earth Sciences, v. 66, pp. 11271136.

Chmura, W.M., Różański, K., Kuc, T., and Gorczyca, Z., 2009, Comparison of two methods for the determination of nitrogen and oxygen isotope composition of dissolved nitrates. Nukleonika, v. 54, pp. 17-23.

Choi, W.J., Lee, S.M., and Ro, H.M., 2003, Evaluation of contamination sources of groundwater $\mathrm{NO}_{3}^{-}$using nitrogen isotope data: A review. Geosciences Journal, v. 7, pp. 81-87.

Choi, B.Y., Yun, S.T., Mayer, B., and Kim, K.H., 2011, Sources and biogeochemical behavior of nitrate and sulfate in an alluvial aquifer: Hydrochemical and stable isotope approaches. Applied Geochemistry, v. 26, pp. 1249-1260.

Curt, M.D., Aguado, P., Sánchez, G., Bigeriego, M., and Fernández, J., 2004, Nitrogen isotope ratios of synthetic and organic sources of nitrate water contamination in Spain. Water, Air, and Soil Pollution, v. 151, pp. $135-142$.

Diédhiou, M., Cissé Faye, S., Diouf, O.C., Faye, S., Faye, A., Re, V., Wohnlich, S., Wisotzky, F., Schulte, U., and Maloszewski, P., 2012, Tracing groundwater nitrate sources in the Dakar suburban area: an isotopic multi-tracer approach. Hydrological Processes, v. 26, pp. 760770.

DiSpirito, A.A., and Hooper, A.B., 1986, Oxygen exchange between nitrate molecules during nitrite oxidation by Nitrobacter. The Journal of Biological Chemistry, v. 261, pp. 10534-10537.

Fenech, C., Rock, L., Nolan, K., Tobin, J., and Morrissey, A., 2012, The potential for a suite of isotope and chemical markers to differentiate sources of nitrate contamination: A review. Water Research, v. 46, pp. 2023-2041.

Fiorentino, G., Ferrio, J.P., Bogaard, A., Araus, J.L., and Riehl, S., 2015, Stable isotopes in archaeobotanical research. Vegetation History and
Archaeobotany, v. 24, 215-227.

Hübner, H., 1986, Isotope effects of nitrogen in the soil and biosphere. In: Fritz, P., and Fontes, J.C. (Eds.), Handbook of Environmental Isotope Geochemistry. Elsevier Science, New York, pp. 361-426.

Iqbal, M.Z., Krothe, N.C., and Spalding, R.F., 1997, Nitrogen isotope indicators of seasonal source variability to groundwater. Environmental Geology, v. 32, pp. 210-218.

Kaown, D., Koh, E.H., Mayer, B., Kim, H., Park, D.K., Park, B.H., and Lee, K.K., 2018, Application of multiple-isotope and groundwater-age data to identify factors affecting the extent of denitrification in a shallow aquifer near a river in South Korea. Hydrogeology Journal, v. 26, pp. 2009-2020.

Kendall, C., 1998, Tracing nitrogen sources and cycling in catchments. In: Kendall, C., and McDonnell, J.J. (Eds.), Isotope Tracers in Catchment Hydrology. Elsevier Science, New York, pp. 519-576.

Kendall, C., Elliott, E.M., and Wankel, S.D., 2007, Tracing anthropogenic inputs of nitrogen to ecosystems. In: Michener, R., and Lajtha, K. (Eds.), Stable isotopes in ecology and environmental science. Blackwell Publishing, Boston, pp. 375-449.

Kim, H., Kaown, D., Mayer, B., Lee, J.-Y., Hyun, Y., and Lee, K.-K., 2015, Identifying the sources of nitrate contamination of groundwater in an agricultural area (Haean basin, Korea) using isotope and microbial community analyses. Science of the Total Environment, v. 533, pp. $566-575$.

Kim, K.H., and Nakai, N., 1988, Isotopic compositions of precipitations and groundwaters in South Korea. Journal of the Geological Society of Korea, v. 24, pp. 37-46.

Koch, P.L., 2007, Isotopic study of the biology of modern and fossil vertebrates. In: Michener, R., and Lajtha, K. (Eds.), Stable Isotopes in Ecology and Environmental Science. Blackwell Publishing, Boston, pp. 99-154.

Koh, D.C., Mayer, B., Lee, K.S., and Ko, K.S., 2010, Land-use controls on sources and fate of nitrate in shallow groundwater of an agricultural area revealed by multiple environmental tracers. Journal of Contaminant Hydrology, v. 118, pp. 62-78.

Komor, S.C., and Anderson, H.W., 1993, Anderson. Nitrogen isotopes as indicators of nitrate sources in Minnesota sand-plain aquifers. Groundwater, v. 31, pp. 260-270.

Krafte-Jacobs, B., Brilli, R., Szabó, C., Denenberg, A., Moore, L., and Salzman, A. L., 1997, Circulating methemoglobin and nitrite/nitrate concentrations as indicators of nitric oxide overproduction in critically ill children with septic shock. Critical Care Medicine, v. 25, pp. 15881593.

Kroopnick, P., and Craig, H., 1972, Atmospheric oxygen: isotopic composition and solubility fractionation. Science, v. 175, pp. 54-55.

Kumar, S., Nicholas, D.J.D., and Williams, E.H., 1983, Definitive ${ }^{15} \mathrm{~N}$ NMR evidence that water serves as a source of ' $\mathrm{O}$ ' during nitrite oxidation by Nitrobacter agilis. FEBS Letters, v. 152, pp. 71-74.

Lee, C., Hristov, A.N., Cassidy, T., Heyler, K., 2011, Nitrogen isotope fractionation and origin of ammonia nitrogen volatilized from cattle manure in simulated storage. Atmosphere, v. 2, pp. 256-270.

Lee, K.S., and Chung, J.I., 1997, Stable isotopic variation of precipitation in Pohang, Korea. Economic and Environmental Geology, v. 30, pp. 321-325.

Lee, K.S., Bong, Y.S., Lee, D., Kim, Y., and Kim, K., 2008, Tracing the sources of nitrate in the Han River watershed in Korea, using $\delta^{15} \mathrm{~N}$ $\mathrm{NO}_{3}{ }^{-}$and $\delta^{18} \mathrm{O}_{-}-\mathrm{NO}_{3}{ }^{-}$values. Science of the Total Environment, v. 395, pp. 117-124.

Li, S.L., Liu, C.Q., Li, J., Liu, X., Chetelat, B., Wang, B., and Wang, F., 2010, Assessment of the sources of nitrate in the Changjiang River, China using a nitrogen and oxygen isotopic approach. Environmental Science \& Technology, v. 44, pp. 1573-1578.

Mayer, B., Boyer, E.W., Goodale, C., Jaworski, N.A., Breemen, N.V., Howarth, R.W., Seitzinger, S., Billen, G., Lajtha, K., Nadelhoffer, K., Dam, D.V., Hetling, L.J., Nosal, M., and Paustian, K., 2002, Source of nitrate in rivers draining sixteen watersheds in the northeastern U.S.: 
Isotopic constraints. Biogeochemistry, v. 57, pp. 171-197.

Mayer, B., Bollwerk, S.M., Mansfeldt, T., Hütter, B., and Veizer, J., 2001, The oxygen isotope composition of nitrate generated by nitrification in acid forest floors. Geochimica et Cosmochimica Acta, v. 65, pp. 27432756.

Michalski, G., Meixner, T., Fenn, M., Hernandez, L., Sirulnik, A., Allen, E., and Thiemens, M., 2004, Tracing atmospheric nitrate deposition in a complex semiarid ecosystem using $\Delta^{17} \mathrm{O}$. Environmental Science \& Technology, v. 38, pp. 2175-2181.

Moon, S.H., Cho, S.H., Lee, K.S., and Yun, U., 2007, The variation of oxygen and hydrogen isotopic composition in precipitation and geothermal waters from the Yuseong catchment. Economic and Environmental Geology, v. 40, pp. 389-401.

Ni, J.-Q., Heber, A.J., Sutton, A.L., Kelly, D.T., Patterson, J.A., and Kim, S.-T., 2010, Effect of swine manure dilution on ammonia, hydrogen sulfide, carbon dioxide, and sulfur dioxide releases. Science of the Total Environment, v. 408, pp. 5917-5923.

Ridder, W.E., and Oehme, F.W., 1974, Nitrates as an environmental, animal, and human hazard. Clinical Toxicology, v. 7, pp. 145-159.

Rock, L., and Ellert, B.H., 2007, Nitrogen-15 and oxygen-18 natural abundance of potassium chloride extractable soil nitrate using the denitrifier method. Soil Science Society of America Journal, v. 71, pp. 355-361.

Rural Development Administration, 2012, Establish and designation of official standard of fertilizers. http://www.rda.go.kr/board/board.do? ccatgId $=\&$ menu $i \mathrm{id}=$ ofc\&boardId $=$ rdalw\&searchKey $=\&$ userJumin $=\&$ searchVal $=\&$ searchSDate $=\&$ prgId=law_rdalwEntry\&portlet_kind $=$ default\&portlet_rowCnt $=4 \&$ mode $=$ view\&portlet_gubun $=1 \&$ currPage $=$ $1 \&$ CONTENT $2=\&$ searchEDate $=\&$ CONTENT $1=\&$ nckUserNm [accessed 7th January 2014].

Shin, W.J., Ryu, J.S., Mayer, B., Lee, K.S., and Kim, I., 2017, Nitrogen, sulfur, and oxygen isotope ratios of animal- and plant-based organic fertilizers used in South Korea. Journal of Environmental Quality, v. 46 , pp. 559-567.

Sigman, D.M., Casciotti, K.L., Andreani, M., Barford, C., Galanter, M., and Böhlke, J.K., 2001, A bacterial method for the nitrogen isotopic analysis of nitrate in seawater and freshwater. Analytical Chemistry, v. 73, pp. 4145-4153.

Silva, S.R., Ging, P.B., Lee, R.W., Ebbert, J.C., Tesoriero, A.J., and Inkpen, E.L., 2002, Forensic applications of nitrogen and oxygen isotopes in tracing nitrate sources in urban environments. Environmental Forensics, v. 3, pp. 125-130.

Shin, W.J., Ryu, J.S., Mayer, B., Lee, K.S., and Lee, S.W., 2014, Natural and anthropogenic sources and processes affecting water chemistry in two South Korean streams. Science of the Total Environment, v. 485486, pp. 270-280.

Singleton, M.J., Woods, K.N., Conrad, M.E., Depaolo, D.J., and Dresel, P.E., 2005, Tracking sources of unsaturated zone and groundwater nitrate contamination using nitrogen and oxygen stable isotopes at the Hanford site, Washington. Environmental Science \& Technology, v. 39, pp. 3563-3570.

Tihansky, A.B., and Sacks, L.A., 1997, Evaluation of nitrate sources using nitrogen-isotope techniques in shallow ground water within selected lake basins in the Central Lakes District, Polk and Highlands Countries, Florida. U.S. Geological Survey Water-Resources Investigations Report 97-4207, Tallahassee, FL, p. 28.

Vitòria, L., Otero, N., Soler, A., and Canals, A., 2004, Fertilizer characterization: Isotopic data (N, S, O, C and Sr). Environmental Science \& Technology, v. 38, pp. 3254-3262.

Wassenaar, L.I., 1995, Evaluation of the origin and fate of nitrate in the Abbotsford Aquifer using the isotopes of ${ }^{15} \mathrm{~N}$ and ${ }^{18} \mathrm{O}$ in $\mathrm{NO}_{3}^{-}$. Applied Geochemistry, v. 10, pp. 391-405.

World Health Organization, 2008, Guidelines for Drinking-water Quality. http://www.who.int/water_sanitation_health/dwq/fulltext.pdf [accessed 8th November 2013].

Xue, D., Baets, B.D., Botte, J., Vermeulen, J., Cleemput, O.V., and Boeckx,
P., 2010, Comparison of the silver nitrate and bacterial denitirification methods for the determination of nitrogen and oxygen isotope ratios of nitrate in surface water. Rapid Communications in Mass Spectrometry, v. 24, pp. 833-840.

Xue, D., Botte, J., De Baets, B., Accoe, F., Nestler, A., Taylor, P., Van Cleemput, O., Berglund, M., and Boeckx, P., 2009, Present limitations and future prospects of stable isotope methods for nitrate source identification in surface- and groundwater. Water Research, v. 43, pp. 1159-1170.

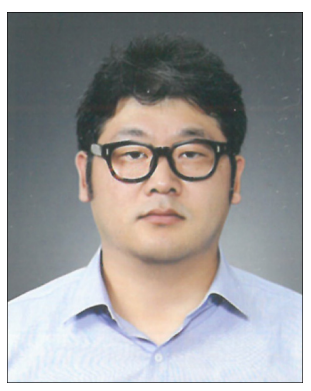

Woo-Jin Shin is a senior researcher in Division of Earth and Environmental Sciences, Korea Basic Science Institute, Korea. He received his Ph.D. from Chungnam National University, Korea. His main research focuses on identifying natural and anthropogenic sources in hydrosphere and pedosphere using chemical compositions and multi-isotopes.

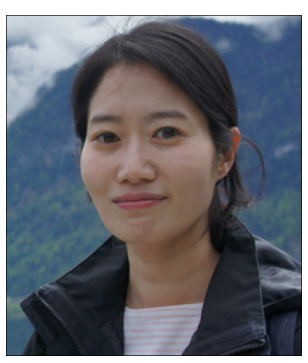

Insu Kim was a postdoctoral fellow in Division of Earth and Environmental Sciences, Korea Basic Science Institute, Korea. She received her Ph.D. from Pukyong National University, Korea. She has studied Environmental Science using bacteria and stable isotopes.

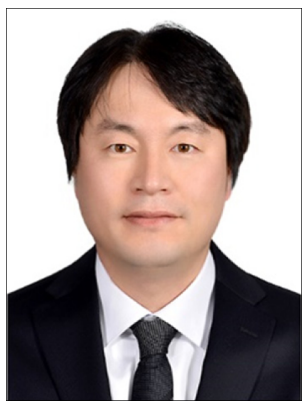

Jong-Sik Ryu is an assistant professor of isotope geochemistry in Department of Earth and Environmental Sciences, Pukyong National University, Busan, Korea. He received his Ph.D. from Seoul National University, Korea. He was a postdoctoral fellow in Department of Earth and Planetary Sciences, Northwestern University, USA, and a principal researcher in Division of Earth and Environmental Sciences, Korea Basic Science Institute, Korea. He won the Young Geologist Award from the Geological Society of Korea, and the Award Certificate from the Ministry of Science and ICT. He specializes in low-temperature geochemistry and non-traditional stable isotope geochemistry.

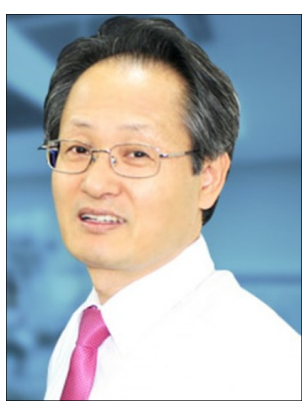

Kwang-Sik Lee is a principal researcher in Division of Earth and Environmental Sciences, Korea Basic Science Institute (KBSI). He received his $\mathrm{Ph}$.D. from Seoul National University in 1997. He was a president of KBSI during Feb. 2016 - Feb. 2019. He is currently working as an adjunct professor of Graduate School of Analytical Science and Technology, Chungnam National University, Korea. His main research focuses on isotope hydrogeology. 